This is a post-peer-review, pre-copyedit version of an article published in the The European Physical Journal Plus. The final authenticated version is available online at: https://doi.org/10.1140/epjp/i2019-13024-2

\title{
MORTAR ANALYSIS OF HISTORIC BUILDINGS DAMAGED BY RECENT EARTHQUAKES IN ITALY
}

Roselli G. ${ }^{a}$, Mirabile Gattia D. ${ }^{b}$, AlShawa O. ${ }^{c}$, Cinaglia P. ${ }^{d}$, Di Girolami G. ${ }^{d}$, Francola C. ${ }^{c}$, Persia F. ${ }^{b}$, Petrucci E. ${ }^{\mathrm{e}}$, Piloni R. ${ }^{\mathrm{a}}$, Scognamiglio F. ${ }^{\mathrm{d}}$, Sorrentino L. ${ }^{\mathrm{c}}$, Zamponi S. ${ }^{\mathrm{a}}$, Liberatore D. ${ }^{\mathrm{c}}$

${ }^{a}$ School of Science and Technology, Chemistry Division, University of Camerino, Via S. Agostino 1, 62032 Camerino, Italy;

graziella.roselli@unicam.it,roberto.piloni@unicam.it,silvia.zamponi@unicam.it

${ }^{b}$ Department of Sustainability SSPT - ENEA-CR Casaccia, Via Anguillarese 301, 00123Rome, Italy;

daniele.mirabile@enea.it,franca.persia@enea.it

"Department of Structural and Geotechnical Engineering, "Sapienza" University of Rome, Rome, Italy; domenico.liberatore@uniroma1.it,omar.alshawa@uniroma1.it,francola.cristina@gmail.com, luigi.sorrentino@uniroma1.it

${ }^{d}$ School of Science and Technology, Technologies and Diagnostics for Conservation and Restoration Laboratory, University of Camerino, Via Pacifici Mazzoni 2, 63100 Ascoli Piceno, Italy; paolo.cinaglia@unicam.it,giuseppe.digirolami@unicam.it,fabrizio.scognamiglio@unicam.it

${ }^{e}$ School of Architecture and Design, Universityof Camerino, 63100 Ascoli Piceno, Italy; enrica.petrucci@unicam.it

\begin{abstract}
The paper presents an experimental study on mortar samples taken from historic and monumental buildings damaged or collapsed following the seismic events in Central Italy (2016-2017). Sixty-one samples were analysed with a set of diagnostic investigations to characterize the mortar and correlate it with the performance of the masonry. The techniques used were: X-Ray diffraction, scanning electron microscopy and microanalysis, differential scanning calorimetry, calcimetry, Fourier-transform infrared spectroscopy, soluble salt analysis by conductimetry and dosage of anionic species by ion chromatography, particle-size analysis, direct shear. Microstructural characterization of the mortars revealed differences in mortar composition depending on their provenance. In particular the samples from Norcia contained large quantities of calcite while in the mortars from Pretare, dolomite was identified. In the case of Amatrice, only a few samples showed crystalline phases and compounds ascribable to binders. These results were largely confirmed by the other chemical and physical analysis performed, and mechanical tests also demonstrated low cohesion. The tests showed that in almost all the samples, poor quality mortars were used, and, in some cases, underachieving binder mortar.
\end{abstract}

\section{Introduction}

In 2016 and early 2017, some dramatic earthquakes severely damaged, and in some cases destroyed, several small towns in Central Italy, causing the loss of human lives and the destruction of old historic town centres. A very high number of buildings were badly damaged in an extended area that includes portions of the Abruzzo, Lazio, Marche and Umbria regions [1]. Fig. 1 and fig. 2 detail earthquakes of magnitude greater than 3.5 occurring between 2015 and 2018, originating respectively in Southern Europe, and in Central Italy. 


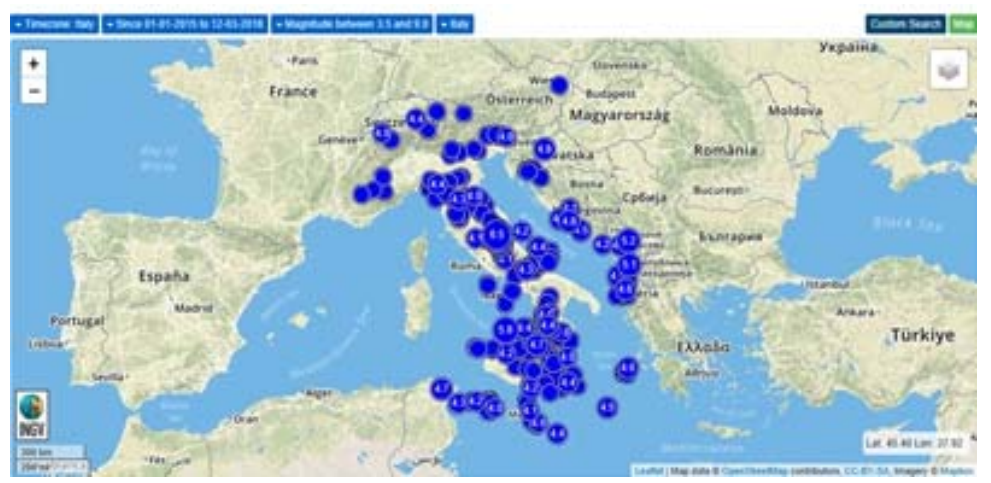

Fig.1. Earthquakes in Southern Europe from 2015 to March 2018, magnitude greater than 3.5 [2]

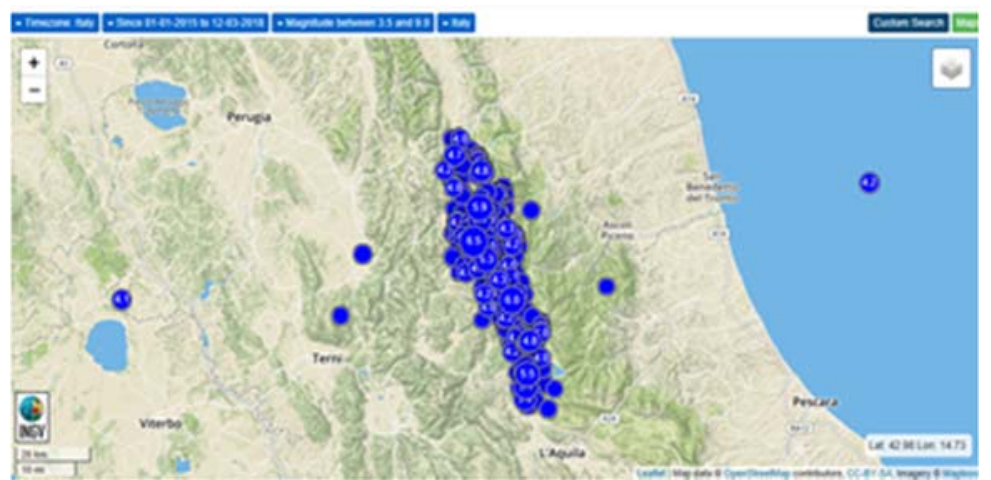

Fig.2. Earthquakes in Central Italy from 2015 to March 2018, magnitude greater than 3.5 [2]

In past centuries, in these regions, construction activity was characterized by the use of local materials and workforce. Until the 1960s, the most common source for such building materials was an area of the Apennines characterized by the outcrop of turbiditic sandstone (Laga Flysch, Messinian), limestone and pelagic marly limestone of the Umbro-Marchigiana series (Mesozoic) [3].

Damage to architectural heritage has shown construction defects, dating back to the original buildings or transformations due to environmental factors and natural aging. For these reasons, it is necessary to investigate in depth the nature of the building system, focusing on the masonry and mortars that contribute to the durability of the overall construction.

The structural behaviour of masonry, particularly under seismic actions, is strongly influenced by masonry bond and mortar quality. Typically, the collapse of existing masonry structures is triggered by: disintegration, out-of-plane mechanisms (overturning or bending), and in-plane mechanisms (shear or bending). Usually, disintegration is the most dangerous mechanism in rubble masonry with two or three leaves, and in the absence of transverse connections (headers). In such conditions, and with the action of eventual external solicitations, the separation between the leaves and the partial or total collapse of the construction occurs. Good quality mortar is essential to delaying/preventing the separation of leaves.

Building constructions in Italian historic centres are largely characterized by load-bearing walls, whose masonry does not always follow the rule of the art $[4,5,6]$. In fact, the masonry construction techniques used in these areas show some deficiencies such as: the presence of mixed materials (sandstone and limestone, usually mined in the area around the building site), the use of undressed or rounded units, an inconsistent or weakly-cemented nucleus. Material quality and appropriate bond are basic requirements for defining wellexecuted masonry walls. Geometry, size and type of units, cross-connections, bond (with horizontal bed joints and the correct stagger of head joints), quantity and quality of mortar, the presence of an inner nucleus, are important details which have to be considered in the analysis of old masonry.

The wall structure does not always display good box-like behaviour, by means of effective connections between walls, and robust horizontal structures connected to vertical structures. Walls show numerous openings, without or with deformed timber lintels. Moreover, renovations carried out after earthquakes occurring in the same area in the last decades of the $20^{\text {th }}$ century modified the structural performance.

Some buildings have particular construction systems, related to the seismic history of the sites. In 1859, a strong earthquake caused victims and numerous collapses in some parts of the old town of Norcia, and the 
Papal States issued a rather effective regulation. The Regolamento required: use of dressed units (river ovoid units were forbidden); control of mortar production (clear sand and lime binder); connections at walls intersections; minimum thickness of wall (recommended tapered vertical cross section). Then, the 1979 Valnerina earthquake damaged other parts of the historic centre, and was followed by interventions to strengthen many buildings.

One of the techniques used was cementitious plaster reinforced by carbon steel welded meshes. This intervention is controversial because of the durability and effect of moisture and salt on existing materials, but it has avoided masonry disintegration, making Norcia a successful case of combined pre-modern and recent regulations [7].

Examples of masonry walls found in little villages in Central Italy can be seen in fig. 3, wherein both internal and external load-bearing panels are shown. Masonry is characterized by material variability (river pebbles, sandstone, travertine), rough-hewn or uneven-size units, irregular bed joints. Sometimes, in order to regularize the courses, timber elements (dormienti) or longer units were inserted. Within the wall thickness there are few bond units (diatoni) and the nucleus is completely inconsistent.
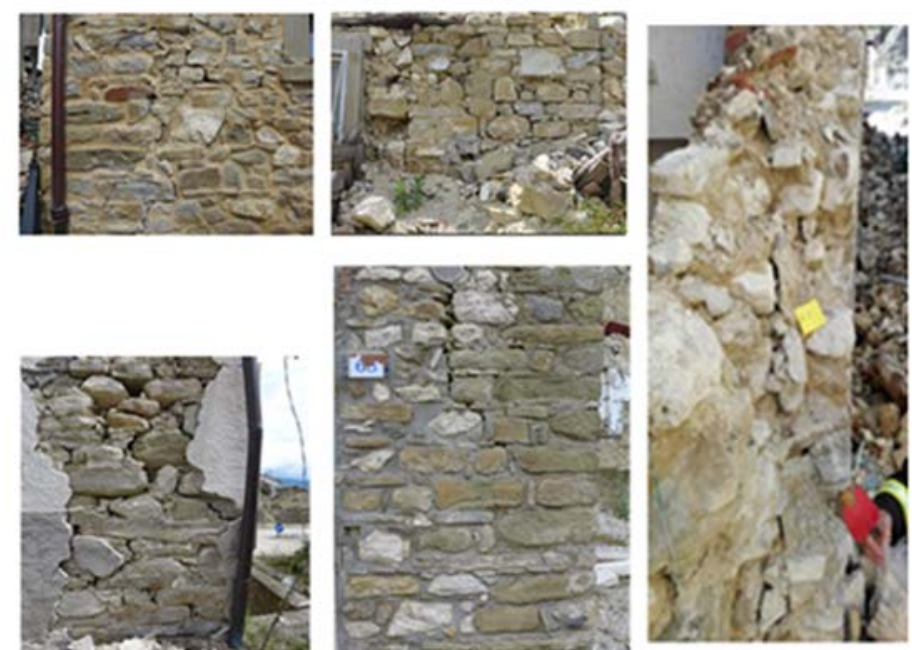

Fig.3. Walls in Pretare (Arquata del Tronto, Marche)

With the aim of gaining a better understanding of masonry damaging mechanisms, in particular those related to mortars used in these constructions, a series of diagnostic investigations were carried out on a set of mortars collected from collapsed buildings.

\section{Experimental methods}

Mortar was sampled in different sites located in Central Italy (Table 1 and fig. 4), namely 20 in Lazio, 16 in Marche and 25 in Umbria. Materials were collected from collapsed masonry located in accessible sites or, otherwise, under the supervision of firefighters and civil protection officers. First of all, the site was visually inspected in order to select sampling points that were significant from a structural point of view. All the samples consist of mortar with bedding function. Sampling activity was carried out in a way that avoided contamination from other materials, such as stones, bricks, plasters, modern cements etc.. 
Table 1.Mortar samples

\begin{tabular}{|c|c|c|c|}
\hline Region & Settlement ID Settlement & Municipality & Sample IDs \\
\hline \multirow{14}{*}{ LAZIO } & 1 Accumoli & Accumoli & $\overline{1}$ \\
\hline & 2 Santa Maria delle Coste & Accumoli & 2 \\
\hline & 3 Amatrice & Amatrice & 3 \\
\hline & 4 Capricchia & Amatrice & 4,5 \\
\hline & 5 Casale & Amatrice & 6 \\
\hline & 6 Cascello & Amatrice & 7,8 \\
\hline & 7 Cossito & Amatrice & 9,10 \\
\hline & 8 Prato & Amatrice & 11 \\
\hline & 9 Preta & Amatrice & $12-14$ \\
\hline & 10 Saletta & Amatrice & 15 \\
\hline & 11 San Capone & Amatrice & 16,17 \\
\hline & 12 Sommati & Amatrice & 18 \\
\hline & 13 Torrita & Amatrice & 19 \\
\hline & 14 Voceto & Amatrice & 20 \\
\hline \multirow{3}{*}{ MARCHE } & 15 Borgo & Arquata del Tronto & $21-26$ \\
\hline & 16 Pretare & Arquata del Tronto & $27-35$ \\
\hline & 17 Trisungo & Arquata del Tronto & 36 \\
\hline \multirow{4}{*}{ UMBRIA } & 18 Ancarano & Norcia & 37 \\
\hline & 19 Campi di Norcia & Norcia & $38-49$ \\
\hline & 20 Norcia & Norcia & $50-60$ \\
\hline & 21 Piedivalle & Norcia & 61 \\
\hline
\end{tabular}

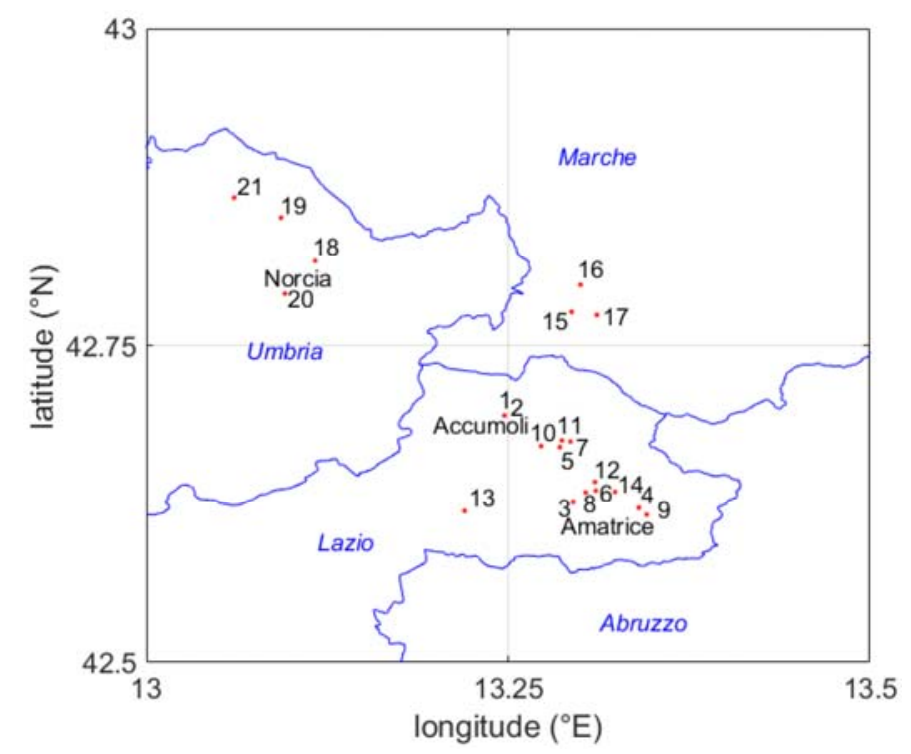

Fig.4. Location of mortar sample sites

At the time of sampling, a record card was filled in with date, location, type of building, point of sampling, and sample quantity (estimated).

An integrated analytical approach was considered so as to obtain a large amount of information and correlate the composition and mechanical behaviour of the mortars with the performance of the masonry. First, the samples collected were inspected in the laboratory, both with the naked eye and a stereomicroscope Olympus SZX12 with digital image acquisition, in order to remove possible spurious impurities, such as wood or coal, and to exclude samples that displayed the effects of external agents. Then, to evaluate grain size distribution, the samples were first roughly cracked into smaller pieces and successively they were sieved. Different mechanical treatments were performed in dry conditions and the material passing through the sieve was weighted and recovered [8]. Particle-size analysis was carried out using the following sieves: 2.000, 1.000, $0.500,0.250,0.106,0.063 \mathrm{~mm}$.

X-Ray Diffraction (XRD) was performed with a Smartlab Rigaku powder diffractometer, with graphite monochromator in the diffracted beam, operated at $40 \mathrm{kV}$ and $30 \mathrm{~mA}$. A suitable quantity of mortar, in the 
form of fine powder, was laid on a zero-background sample holder. Patterns were obtained from 2 to $902 \theta$ degree, at steps of $0.042 \theta$ degree and $12 \mathrm{~s}$ per step. Material passing $0.063 \mathrm{~mm}$ sieve further milled in an agate mortar was used for XRD analysis, in order to identify the mineralogical phases present in the samples $[9,10]$.

A Scanning Electron Microscope (SEM) EVO MA15 equipped with Energy dispersive spectroscopy (EDS) was used to study the morphology of the different fractions constituting the mortars and to perform microanalysis.

Differential Scanning Calorimetry (DSC) was performed with a Mettler Toledo HPDSC with a temperature programmed to run from room temperature to $650{ }^{\circ} \mathrm{C}$ at a heating rate of $5 \mathrm{~K} / \mathrm{min}$ and $50 \mathrm{ml} / \mathrm{min}$ of Ar flux. The technique makes it possible, by simply heating the sample in a wide temperature range, generally from room temperature to $650^{\circ} \mathrm{C}$, to reveal the heat involved in eventual decompositions or transformations, as phase ones, in a small quantity of samples in solid or even liquid form.

Analysis by Fourier-Transform Infrared Spectroscopy (FT-IR) was carried out on mortar samples ground in a agate mortar and then passed completely through a $0.125 \mathrm{~mm}$ sieve. A Perkin Elmer Spectrum 100 was used in ATR mode (Attenuated Total Reflectance). For each sample two acquisitions were performed.

Calcimetry was performed, using the gas-volumetric Dietrich-Fruheling method. The sample was ground manually with an agate mortar until it could be completely passed through a $0.063 \mathrm{~mm}$ sieve, then dried into a thermobalance at $60{ }^{\circ} \mathrm{C}$ up to constant mass. The sample was treated with a reagent based on hydrochloric acid, which decomposes the carbonates present by $\mathrm{CO}_{2}$ development, as regulated by UNI 11140: 2004. This technique made it possible to evaluate with greater precision, than through analysis in FT-IR spectroscopy ATR, the quantity of carbonates present in the samples.

Soluble salt analysis by conductimetry and measurement of anionic species by ion chromatography were carried out. From the conductivity value of the solutions - the formula indicated in the DIMOS document, part II module 3, ICR, 1978 was applied - the percentage of soluble salts present in the samples was estimated. Analysis of soluble salts procedure (UNI 11087: 2003) was followed: the sample was dried in an oven at $60{ }^{\circ} \mathrm{C}$ for about $24 \mathrm{~h}$, then ground manually within an agate mortar until it completely passed through a $0.125 \mathrm{~mm}$ sieve. The samples were weighed $(95 \mathrm{mg}$ up to $105 \mathrm{mg}$ ) and treated in a thermobalance at a temperature of $60{ }^{\circ} \mathrm{C}$ up to a constant mass. One hundred $\mathrm{ml}$ of bidistilled $\mathrm{H}_{2} \mathrm{O}$, whose conductivity was previously measured, were added to the sample and placed in a flat-bottomed glass container. The container was hermetically sealed to prevent evaporation and slowly stirred for $2 \mathrm{~h}$. Then, residuals were left to deposit for about $30 \mathrm{~min}$. Finally, conductivity was measured with a XS Multiparameter, model PC 70. The suspension obtained was then filtered (black band filter) and the solution was used for the measurements of the single ionic species by ion chromatography.

Ion chromatograms were recorded with a Metrohm Ion Chromatograph 761 Compact with chemical integrated Metrohm suppressor module (MSM) and a METROSEP A Supp. 5 150/4.0 separation column. A conductivity detector was used to identify the main anionic species present in the mortar solution. Introduction volume was typically $1.5 \mathrm{ml}$ and the loop volume was $20 \mu \mathrm{l}$. Sartorius $0.45 \mu \mathrm{m} \mathrm{RC-Membrane}$ PP-Housing filters were used to remove particles. Three repetitions for each analysis were performed.

Direct shear test was performed on the fraction of non-cohesive samples with particle-size less than or equal to $2 \mathrm{~mm}$. For each sample, three levels of normal stress were applied: $\sigma_{n}=0.05,0.10,0.20 \mathrm{MPa}$. For each normal stress level, a cyclic test provided the maximum $\left(\tau_{\max }\right)$ and the residual $\left(\tau_{\text {res }}\right)$ shear stresses. Based on direct shear test, cohesion $c$ and friction coefficient $\mu$ were determined.

\section{Results and discussion}

\subsection{Sieving process and grain size distribution}

Curves in fig. 5 show the preponderance of a coarse fraction in mortars from Umbria, in particular those from Norcia, contrary to a fine fraction in samples from Marche, especially from Pretare. Particle-size analysis highlighted the great compositional variability of the sampled mortars, not only between different 
regions but also within the same regional context, reflecting the extreme typicality of each of the small towns of Central Italy and possibly of each building site, if not of each mortar batch.

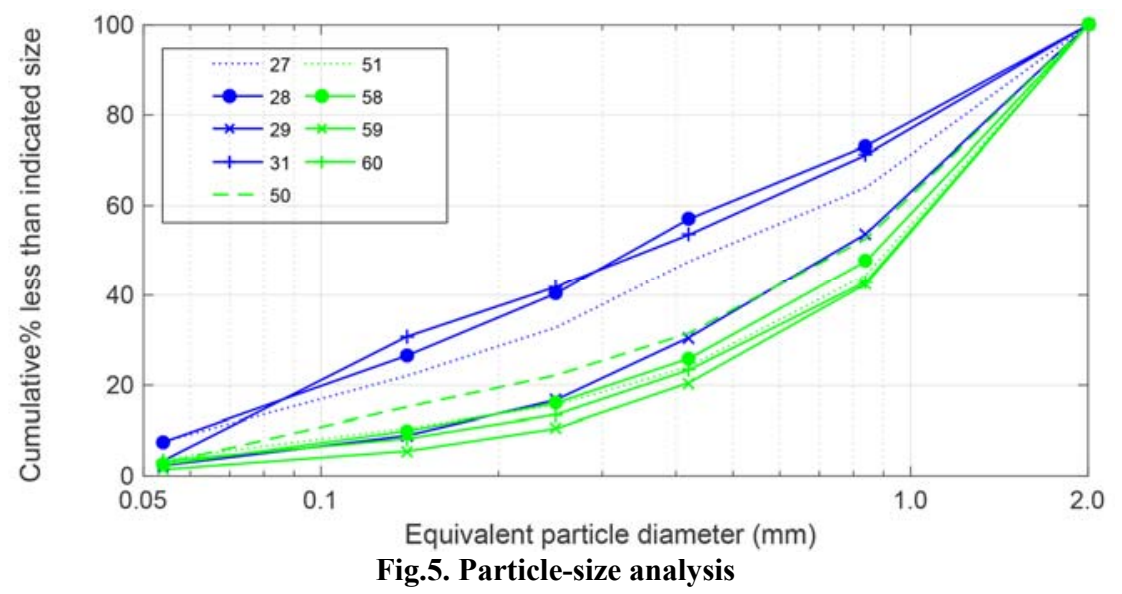

\subsection{X-Ray diffraction}

Fig. 6 shows typical X-Ray diffractograms of mortars from settlements in the municipality of Amatrice.

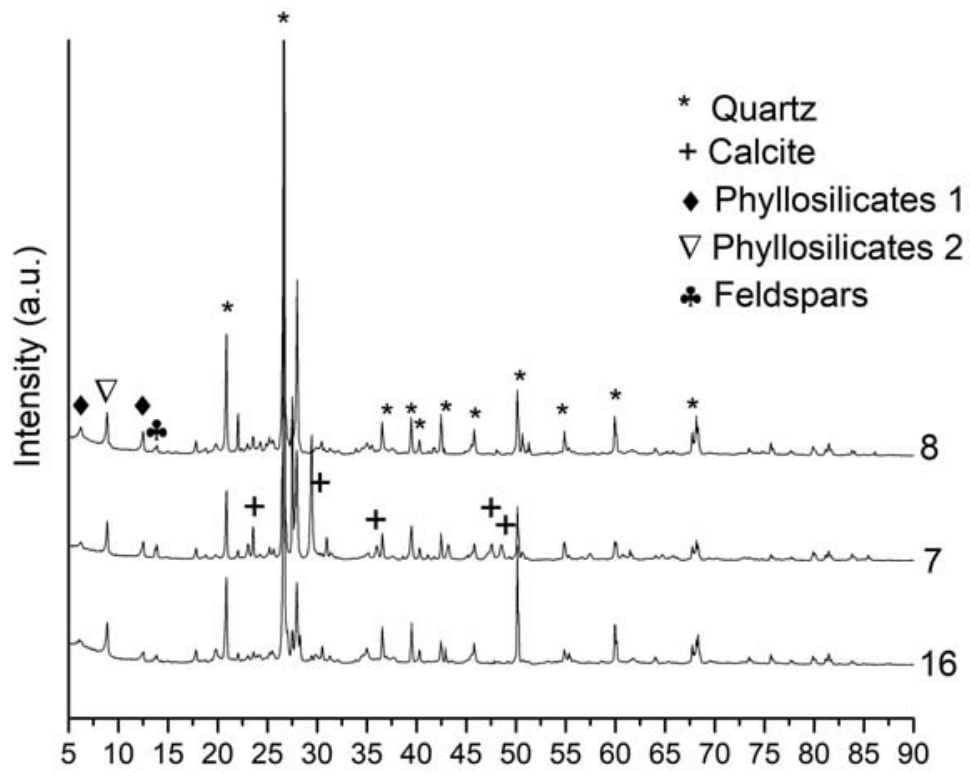

29

Fig.6. XRD patterns of some samples from settlements in the municipality of Amatrice

XRD showed that the main phases present in these samples are quartz, phyllosilicates and feldspars, whereas few samples contained calcite or other traces of different binders. The samples from the area of Amatrice display crystalline phases related mainly to inert fractions of the mortar.

Differently from Amatrice, samples from Norcia showed the presence of large quantities of calcite, quartz, traces of phyllosilicates ( in particular Clinochlore) and in some samples, gypsum (fig. 7). 


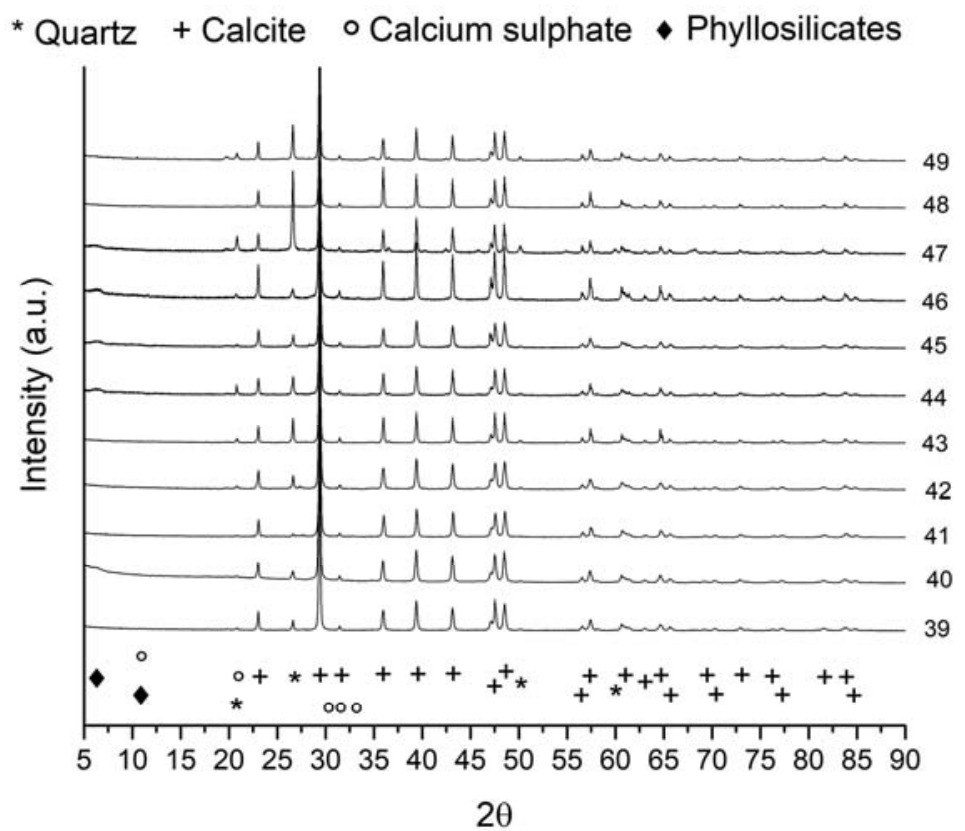

Fig.7. XRD patterns of samples from Saint Salvatore Church in Campi di Norcia

Differently from Amatrice and Norcia, dolomite was found in the mortars from Pretare and Borgo. Fig. 8 shows X-Ray diffractograms of samples from the churches of Saints Peter and Paul (Borgo, 21, 24), Saint Francis (Borgo, 22, 25-26), and Saint Rocco (Pretare, 27-28). In all these samples, large quantities of dolomite were found, together with calcite, quartz, phyllosilicates and feldspars.
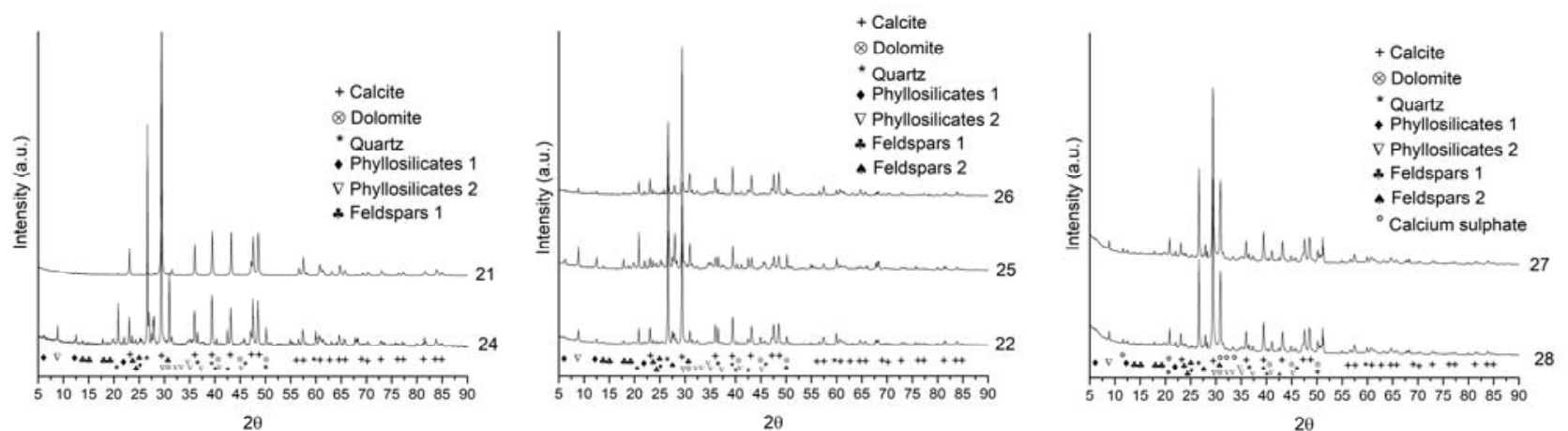

Fig.8. X-Ray diffractograms of samples from the churches of Saints Peter and Paul (Borgo, 21, 24), Saint Francis (Borgo, 22, 25-26), Saint Rocco (Pretare, 27-28)

$\mathrm{X}$-Ray diffraction is a technique that can discern among crystalline phases but not distinguish among $\mathrm{CaCO}_{3}$ due to inert or binder fraction. However in mortars, lower concentrations of $\mathrm{CaCO}_{3}(15-20 \%$ of the whole sample) could be related to the binder, whereas high concentrations (80 to 100\%) could be associated to aggregate [11].

The mortars sampled in Pretare and neighbouring areas showed the presence of dolomite, calcite and quartz with some feldspars and phyllosilicates. Dolomite in these mortars was probably used as aggregate rather than binder. In fact hydromagnesite, $\mathrm{Mg}_{5}\left(\mathrm{CO}_{3}\right)_{4}(\mathrm{OH})_{2} \cdot 4 \mathrm{H}_{2} \mathrm{O}$, which is the main product resulting from the curing of magnesian lime mortars, is not present in these samples. This phase presents a fine plate-like aspect and its formation is directly correlated to mortar mechanical strength [12]. It has been said that dolomitic mortars are not recommended in dry areas, as shrinkage and pore networks negatively impact water transfer. Moreover, calcareous aggregate is preferred to dolomitic aggregate, as it results in better mortar cohesion [13]. The materials used to prepare the mortars analysed were probably extracted from quarries near the corresponding settlements. In a future work, sampling from known quarries will be performed in order to link digging site to construction site.

\subsection{Scanning electron microscopy and microanalysis}


SEM-EDS was used for the microstructural characterization of the fraction constituting the mortar and for microanalysis, with the aim of evaluating differences among the samples from various regions.

Fig. 9 shows a representative selected set of SEM images of the samples a) 7, b) 3, c) 27 and d) 44, respectively from Cascello, Amatrice, Pretare and Norcia. The numbers refer to EDS point analysis and the results are summarized below:

a) 1: $\mathrm{Si}, \mathrm{O} ; 2$ : $\mathrm{Si}, \mathrm{O}, \mathrm{Al}, \mathrm{Na}, \mathrm{K}, \mathrm{Ca} ; 3: \mathrm{Si}, \mathrm{O}$, and traces of $\mathrm{Al}, \mathrm{K}$ and $\mathrm{Fe} ; 4: \mathrm{Si}, \mathrm{O}, \mathrm{Al}$ and $\mathrm{K}$, and traces of $\mathrm{Na}$; 5: $\mathrm{Si}, \mathrm{O}, \mathrm{Al}, \mathrm{K}$, and traces of $\mathrm{Mg}, \mathrm{Na}, \mathrm{Fe}$;

b) 1-10: $\mathrm{Si}, \mathrm{O} ; 11: \mathrm{Si}, \mathrm{O}$, and traces of $\mathrm{Mg}, \mathrm{Al}, \mathrm{K} ; 12: \mathrm{Si}, \mathrm{O}, \mathrm{K}, \mathrm{Al}, \mathrm{Mg}$, and traces of Fe;

c) 1: $\mathrm{Ca}, \mathrm{C}, \mathrm{O}$, and traces of $\mathrm{Mg}, \mathrm{Fe} ; 2: \mathrm{Ca}, \mathrm{Mg}, \mathrm{C}, \mathrm{O}, \mathrm{Si}$; 3: $\mathrm{Ca}, \mathrm{C}, \mathrm{O}$, and traces of $\mathrm{Mg}, \mathrm{Al}, \mathrm{Si}$; 4: Ca, C, O, and small quantities of $\mathrm{Mg}$ and $\mathrm{Si}$;

d) 1: $\mathrm{Si}, \mathrm{O}$; 2: $\mathrm{Si}, \mathrm{O}$; 3: $\mathrm{Si}, \mathrm{O}, \mathrm{Ca}, \mathrm{C}$, and traces of $\mathrm{Mg}, \mathrm{Al}, \mathrm{K}$; 4: $\mathrm{Ca}, \mathrm{C}, \mathrm{O}$, and a few traces of $\mathrm{Al}, \mathrm{Mg}, \mathrm{Si}, \mathrm{K}$, and $\mathrm{Fe} ; 5: \mathrm{Ca}, \mathrm{C}, \mathrm{O}$, and traces of $\mathrm{Mg}$.

EDS results are largely in agreement with those obtained by X-Ray diffraction. The large presence of $\mathrm{Si}, \mathrm{Al}$, $\mathrm{K}, \mathrm{Mg}, \mathrm{Na}$ and $\mathrm{O}$ can be ascribed to the presence of feldspars and phyllosilicates in these samples. Moreover, it should be noticed that some samples observed present fractions containing mainly $\mathrm{Ca}, \mathrm{C}$ and $\mathrm{O}$ and which can be correlated to calcite phase, in particular in samples from Norcia and Pretare. In this last case, high quantities of $\mathrm{Mg}$ can also be detected, together with $\mathrm{Ca}, \mathrm{C}$ and $\mathrm{O}$. These results could reinforce the hypothesis that calcite and dolomite were used also as inert materials in the mortar preparation.

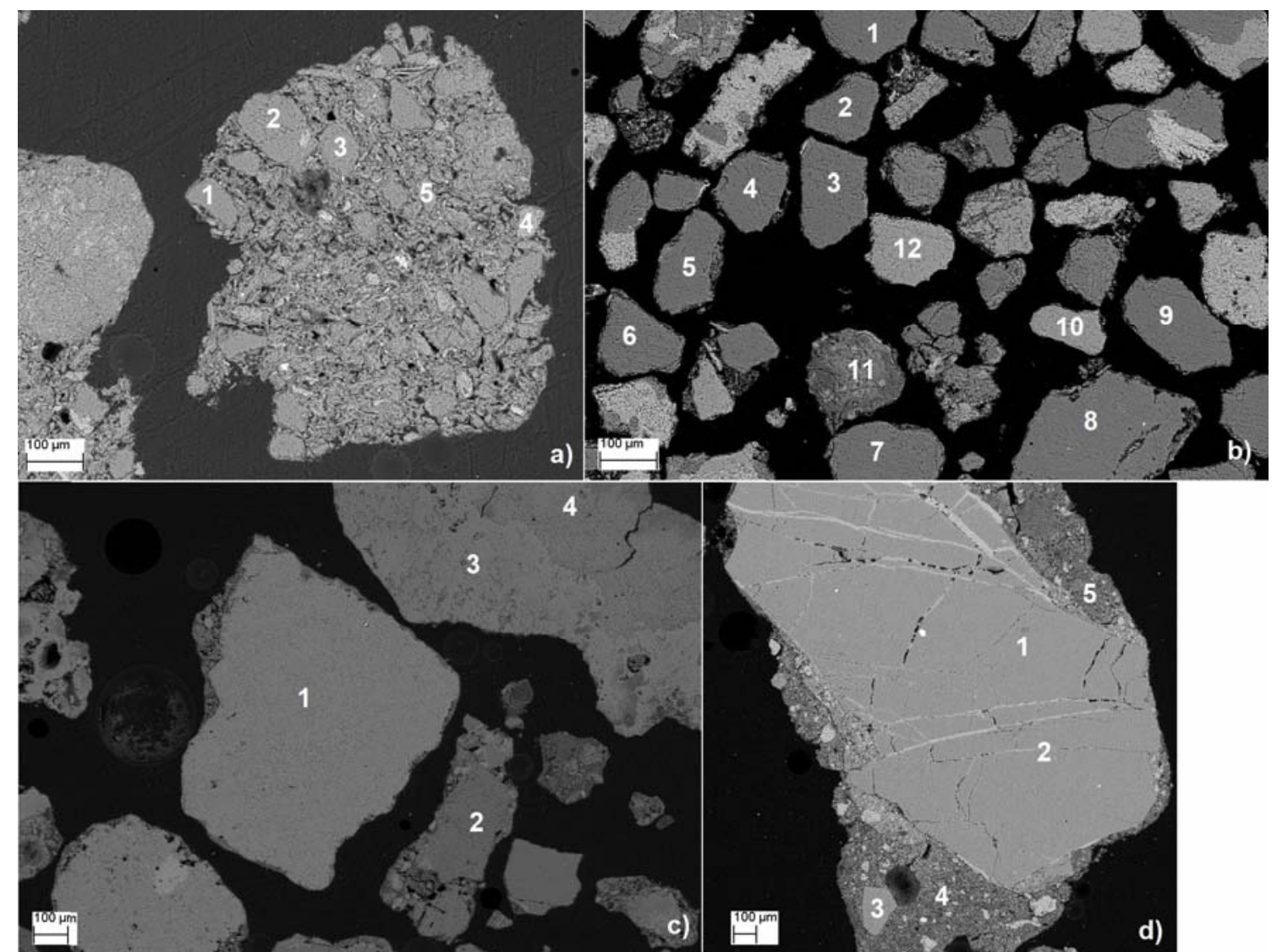

Fig.9. Scanning electron microscope images of samples from a) Cascello (7, Amatrice), b) Amatrice (3), c) Pretare (27, Arquata del Tronto) and d) Norcia (44)

\subsection{Differential scanning calorimetry}

DSC was used with the aim of detecting possible amorphous, inorganic or organic compounds. Fig. 10 shows differential scanning calorimetric curves of samples from the church of Saint Francis in Borgo, together with a pure $\mathrm{CaCO}_{3}$ reference curve. The graphs demonstrate low quantity of water adsorbed in the samples $(<1 \%)$ in the range from room temperature to $120^{\circ} \mathrm{C}$, and some exothermic phenomena which could be correlated to dolomite decomposition $\left(400-500^{\circ} \mathrm{C}\right)$, which takes place at different temperatures $[14$, 
15]. Confirming XRD results, quartz is still present in these samples, as evident from the alpha to beta inversion at $573{ }^{\circ} \mathrm{C}$.

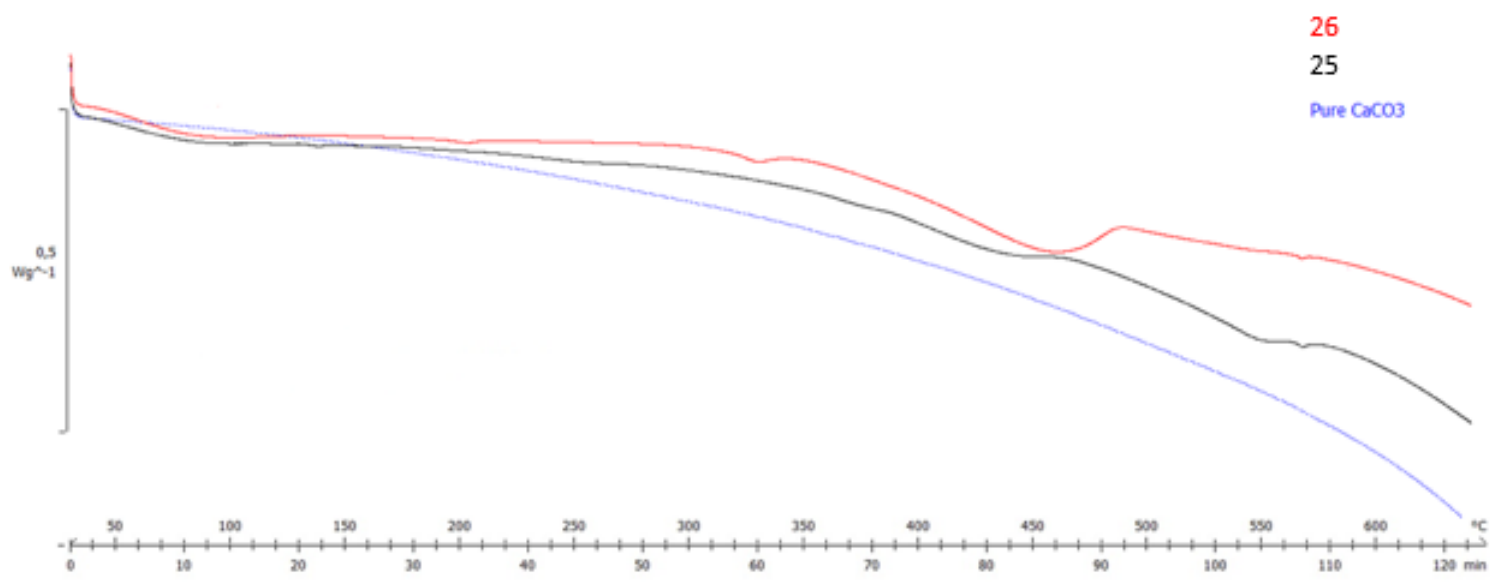

Fig.10. Differential scanning calorimetric curves of samples from the church of Saint Francis in Borgo. CaCOz curve is shown as reference

Air lime and dolomitic mortars are low hygroscopic, and this feature allows them to be identified [10]. In the samples analysed, the water adsorbed, which is lost in the heating process, is lower than $1 \%$.

\subsection{Fourier-transform infrared spectroscopy}

FT-IR analysis made it possible to have an overview of the composition of the mortars [16] and, with regard to carbonates, silicates and sulphates, the intensity of their stretching signals were used to obtain a semiquantitative evaluation (Table 2). Table 2 allows us to draw the following considerations:

- most of the samples from Amatrice (Lazio) did not display the characteristic signals of carbonates but only those of silicates;

- mortars collected in the settlements of the municipalities of Arquata del Tronto (Marche) and Norcia (Umbria) show intense signals of carbonates and, in some cases, also of silicates.

Table 2.FT-IR results from Lazio (Sample ID: 1 to 20), Marche (Sample ID: 21 to 36) and Umbria (Sample ID: 39 to 61) regions. The number of ' $x$ ' indicates the intensity of the stretching signals of carbonates, silicates and sulphates

\begin{tabular}{|c|c|c|c|c|c|c|c|c|c|c|c|}
\hline $\begin{array}{r}\text { Sample } \\
\text { ID } \\
\end{array}$ & $\mathrm{CO}_{3}{ }^{2-}$ & $\begin{array}{l}\text { FT-IR } \\
\mathrm{SiO}_{4}^{4-} \\
\end{array}$ & $\mathrm{SO}_{4}^{2-}$ & $\begin{array}{r}\text { Sample } \\
\text { ID }\end{array}$ & $\mathrm{CO}_{3}{ }^{2-}$ & $\begin{array}{l}\text { FT-IR } \\
\mathrm{SiO}_{4}^{4-} \\
\end{array}$ & $\mathrm{SO}_{4}^{2-}$ & $\begin{array}{c}\text { Sample } \\
\text { ID }\end{array}$ & $\mathrm{CO}_{3}{ }^{2-}$ & $\begin{array}{l}\text { FT-IR } \\
\mathrm{SiO}_{4}^{4-} \\
\end{array}$ & $\mathrm{SO}_{4}{ }^{2-}$ \\
\hline 1 & $\mathrm{xxx}$ & $\mathrm{xx}$ & & 20 & (x) & $\mathrm{xxx}$ & & 42 & $\mathrm{xxx}$ & $\mathrm{x}$ & \\
\hline 2 & & & & 21 & $\mathrm{xxx}$ & & & 43 & $\mathrm{xxx}$ & (x) & \\
\hline 3 & $\mathrm{xx}$ & $\mathrm{xxx}$ & & 22 & $\mathrm{XxX}$ & $\mathrm{xx}$ & & 44 & $\mathrm{xxx}$ & (x) & \\
\hline 4 & $\mathrm{xxx}$ & $\mathrm{xxx}$ & & 23 & $\mathrm{xxx}^{*}$ & $\mathrm{xx}$ & & 45 & $\mathrm{xxx}$ & $\mathrm{x}$ & \\
\hline 5 & & $\mathrm{xxx}$ & & 24 & $\mathrm{xxx}$ & $\mathrm{xxx}$ & & 46 & $\mathrm{xxx}$ & $\mathrm{x}$ & \\
\hline 6 & & $\mathrm{xxx}$ & & 25 & $\mathrm{xxx}$ & $\mathrm{xx}^{* *}$ & & 47 & $\mathrm{xxx}$ & $\mathrm{xx}$ & \\
\hline 7 & $\mathrm{xx}$ & $\mathrm{xxx}$ & & 26 & $\mathrm{xxx}$ & $\mathrm{x}^{* *}$ & & 48 & $\mathrm{xxx}$ & $\mathrm{xx}$ & \\
\hline 8 & & $\mathrm{xxx}$ & & 27 & $\mathrm{xxx}^{*}$ & $\mathrm{x}$ & & 49 & $\mathrm{xxx}$ & $\mathrm{x}$ & \\
\hline 9 & & $\mathrm{xxx}$ & & 28 & $\mathrm{xxx}^{*}$ & $\mathrm{x}$ & & 50 & $\mathrm{xxx}$ & $\mathrm{x}$ & \\
\hline 10 & (x) & $\mathrm{xxx}$ & & 29 & $\mathrm{xxx}^{*}$ & (x) & & 52 & $\mathrm{xxx}$ & (x) & \\
\hline 11 & (x) & $\mathrm{xxx}$ & & 30 & $\mathrm{xxx}^{*}$ & $\mathrm{x}$ & & 53 & $\mathrm{xxx}$ & $\mathrm{x}$ & \\
\hline 12 & $\mathrm{x}$ & $\mathrm{xxx}$ & & 32 & $\mathrm{xxx} *$ & $\mathrm{x}$ & & 54 & $\mathrm{xxx}$ & $\mathrm{x}$ & \\
\hline 13 & $\mathrm{x}$ & $\mathrm{xxx}$ & & 33 & XXX & $\mathrm{x}$ & & 55 & $\mathrm{xxx}$ & $\mathrm{x}$ & \\
\hline 14 & $\mathrm{x}$ & $\mathrm{xxx}$ & & 34 & $\mathrm{xxx}$ & $\mathrm{x}$ & & 56 & $\mathrm{xxx}$ & $\mathrm{xx}$ & \\
\hline 15 & & & & 35 & $\mathrm{xxx}^{*}$ & $(\mathrm{x})$ & & 57 & $\mathrm{xxx}$ & $\mathrm{x}$ & \\
\hline 16 & & $\mathrm{xxx}$ & & 36 & $\mathrm{xxx}$ & $\mathrm{xx}^{* *}$ & & 58 & & & \\
\hline 17 & (x) & $\mathrm{xxx}$ & & 39 & $\mathrm{xxx}$ & (x) & & 59 & & & \\
\hline 18 & & $\mathrm{Xxx}$ & & 40 & $\mathrm{xxx}$ & $\mathrm{x}$ & & 60 & & & \\
\hline 19 & & $\mathrm{xxx}$ & & 41 & $\mathrm{xxx}$ & & & 61 & $\mathrm{xxx}$ & $\mathrm{x}$ & \\
\hline
\end{tabular}

* presence of dolomite, in addition to calcite 


\subsection{Calcimetry}

With regard to the eighteen samples from Amatrice, twelve of them have very low carbonate content. This indicates that the mortar is characterized by the absence of binder, as evidenced by XRD.

Most samples from Norcia and Arquata del Tronto, however, have a percentage of carbonates higher than $30 \%$. More than two thirds of the samples ( 25 out of 36 ) have a percentage of carbonates well above $50 \%$, indicating that carbonates, too, were used as aggregates, while in the case of Amatrice, a silicatic type of aggregate is present.

\subsection{Soluble salt analysis by conductimetry and dosage of anionic species by ion chromatography}

As can be seen in Table 3, the percentage of soluble salts in most Amatrice mortars is below 3\%, with the exception of samples 4 and 11, which are barely above. The mortars of Arquata and Norcia are, instead, characterized by values between 2 and $10 \%$. Concerning the concentration of the various anionic species (Table 3), the following considerations can be made:

- the sulphates were present in low quantities, below 3 ppm (except for samples 1, 3, 28 and 36);

- the presence of chlorides in the samples is negligible: only four samples exceed 2 ppm $(11,33,36,45)$;

- regarding nitrates, there is a very heterogeneous situation: most of the samples show negligible concentrations (lower than $2 \mathrm{ppm}$ ) except for twelve samples with higher concentrations;

- the presence of fluorides and phosphates was not detected (except for sample 3).

Table 3. Percentage of Soluble Salts (SS) and concentration of anionic species (average value of three measurements) in the samples from Lazio (Sample ID: 1 to 20), Marche (Sample ID: 21 to 36) and Umbria (Sample ID: 39 to 61) regions

\begin{tabular}{|c|c|c|c|c|c|c|c|}
\hline $\begin{array}{l}\text { Sample } \\
\text { ID }\end{array}$ & $\begin{array}{c}\text { Conductivity } \\
{[\mu \mathrm{S}]}\end{array}$ & $\begin{array}{l}\text { SS } \\
{[\%]}\end{array}$ & \multicolumn{5}{|c|}{ [ppm] } \\
\hline $\begin{array}{l}1 \\
2\end{array}$ & 64 & 3.99 & - & $1.31 \pm 0.10$ & $3.31 \pm 0.17$ & - & $9.32 \pm 0.07$ \\
\hline 3 & 47 & 2.96 & 0.53 & $0.35 \pm 0.02$ & - & 1.36 & $3.41 \pm 0.24$ \\
\hline 4 & 51.3 & 3.05 & - & $2.01 \pm 0.06$ & $3.82 \pm 0.10$ & - & $1.16 \pm 0.12$ \\
\hline 5 & 29.5 & 1.71 & - & 0.15 & 0.16 & - & 2.15 \\
\hline 6 & 17.4 & 1.06 & - & $0.39 \pm 0.03$ & $0.74 \pm 0.08$ & - & $0.66 \pm 0.19$ \\
\hline 7 & 45 & 2.67 & - & $0.43 \pm 0.04$ & - & - & $0.51 \pm 0.11$ \\
\hline 8 & 7.8 & 0.40 & - & $0.42 \pm 0.02$ & - & - & $0.63 \pm 0.11$ \\
\hline 9 & 15.6 & 0.89 & - & $0.49 \pm 0.02$ & $0.71 \pm 0.14$ & - & $>0.5$ \\
\hline 10 & 33.3 & 2.06 & - & $0.42 \pm 0.03$ & $0.74 \pm 0.12$ & - & $>0.5$ \\
\hline 11 & 45 & 3.00 & - & $3.10 \pm 0.10$ & $8.50 \pm 0.28$ & - & 0.52 \\
\hline 12 & 39 & 2.48 & - & $0.40 \pm 0.02$ & $0.40 \pm 0.01$ & - & - \\
\hline 13 & 35.2 & 2.23 & - & $0.34 \pm 0.02$ & - & - & $>0.5$ \\
\hline 14 & 42.2 & 2.59 & - & $0.59 \pm 0.01$ & $2.73 \pm 0.34$ & - & $1.05 \pm 0.10$ \\
\hline 15 & & & & & & & \\
\hline 16 & 18 & 1.04 & - & $0.52 \pm 0.07$ & $0.91 \pm 0.12$ & - & $0.71 \pm 0.07$ \\
\hline 17 & 44 & 2.81 & - & $1.18 \pm 0.12$ & - & - & $1.36 \pm 0.14$ \\
\hline 18 & 19.7 & 1.20 & - & $0.47 \pm 0.04$ & $0.53 \pm 0.19$ & - & $>0.5$ \\
\hline 19 & 21 & 1.19 & - & $0.42 \pm 0.05$ & - & - & $0.56 \pm 0.10$ \\
\hline 20 & 38.3 & 2.21 & - & $0.43 \pm 0.03$ & $1.80 \pm 0.27$ & - & $>0.5$ \\
\hline 21 & 45.3 & 2.91 & - & $0.43 \pm 0.02$ & 0.647026 & - & $>0.5$ \\
\hline 22 & 92 & 5.90 & - & $0.98 \pm 0.04$ & $19.17 \pm 0.17$ & - & $1.00 \pm 0.04$ \\
\hline 23 & 54 & 3.42 & - & $0.57 \pm 0.11$ & 0.45 & - & $0.90 \pm 0.17$ \\
\hline 24 & 40.2 & 2.36 & - & $0.38 \pm 0.03$ & - & - & $>0.5$ \\
\hline 25 & 56.3 & 3.64 & - & $0.83 \pm 4.6 \mathrm{E}-3$ & 0.74 & - & - \\
\hline 26 & 82.5 & 5.25 & - & $1.08 \pm 0.16$ & $13.56 \pm 1.22$ & - & - \\
\hline 27 & 78.9 & 4.96 & - & $0.50 \pm 0.03$ & $0.45 \pm 0.05$ & - & $>0.5$ \\
\hline 28 & 65.2 & 3.97 & - & $1.04 \pm 0.17$ & $1.50 \pm 0.29$ & - & $8.84 \pm 1.05$ \\
\hline 29 & 125.4 & 8.27 & - & $0.33 \pm 5.17 \mathrm{E}-3$ & $0.30 \pm 0.20$ & - & $0.51 \pm 0.13$ \\
\hline 30 & 45.5 & 2.79 & - & $0.52 \pm 7.33 \mathrm{E}-3$ & - & - & $0.67 \pm 0.05$ \\
\hline 32 & 61 & 4.12 & - & $0.50 \pm 0.07$ & $1.15 \pm 0.20$ & - & $0.92 \pm 0.10$ \\
\hline 33 & 158 & 10.03 & - & 2.57 & 13.14 & - & 0.65 \\
\hline
\end{tabular}




\begin{tabular}{|c|c|c|c|c|c|c|c|}
\hline 35 & 66 & 3.99 & - & $0.59 \pm 0.09$ & 0.24 & - & $1.07 \pm 0.12$ \\
\hline 36 & 93.5 & 5.91 & - & $5.00 \pm 0.05$ & $13.70 \pm 1.79$ & - & $3.87 \pm 0.64$ \\
\hline 39 & 44 & 2.61 & - & $0.42 \pm 0.02$ & $0.56 \pm 0.10$ & - & $0.47 \pm 0.04$ \\
\hline 40 & 44.4 & 2.57 & - & $0.42 \pm 0.04$ & 0.49 & - & $>0.5$ \\
\hline 41 & 54.3 & 3.25 & - & $1.40 \pm 0.08$ & $0.39 \pm 0.04$ & - & $2.17 \pm 0.07$ \\
\hline 42 & 39.5 & 2.41 & - & $0.42 \pm 9.17 \mathrm{E}-4$ & - & - & $>0.5$ \\
\hline 43 & 39 & 2.37 & - & $0.34 \pm 3.67 \mathrm{E}-4$ & $0.36 \pm 0.04$ & - & $>0.5$ \\
\hline 44 & 48 & 2.92 & - & $0.89 \pm 0.08$ & $1.06 \pm 0.24$ & - & $1.18 \pm 0.21$ \\
\hline 45 & 80 & 4.73 & - & $3.87 \pm 0.08$ & $17.01 \pm 0.84$ & - & $>0.5$ \\
\hline 46 & 40 & 2.40 & - & $0.59 \pm 0.13$ & $0.31 \pm 0.02$ & - & $0.60 \pm 0.09$ \\
\hline 47 & 62 & 3.81 & - & $2.03 \pm 0.13$ & $5.81 \pm 0.20$ & - & $0.75 \pm 0.13$ \\
\hline 48 & 43.5 & 2.60 & - & $0.46 \pm 0.02$ & - & - & - \\
\hline 49 & 43.9 & 2.61 & - & $0.48 \pm 0.03$ & $0.46 \pm 0.10$ & - & $>0.5$ \\
\hline 50 & 40 & 2.45 & & & & & \\
\hline 52 & 51.7 & 3.08 & - & $0.47 \pm 0.03$ & $1.39 \pm 0.24$ & - & $0.53 \pm 0.13$ \\
\hline 53 & 45 & 2.73 & - & $2.06 \pm 0.05$ & $1.13 \pm 0.04$ & - & $0.77 \pm 0.18$ \\
\hline 54 & 56.6 & 3.64 & - & $1.96 \pm 0.05$ & $6.10 \pm 0.56$ & - & $1.76 \pm 0.12$ \\
\hline 55 & 39.5 & 2.63 & - & $0.46 \pm 0.02$ & - & - & $0.58 \pm 0.13$ \\
\hline 56 & 44.4 & 2.71 & - & $0.48 \pm 0.03$ & $0.32 \pm 0.02$ & - & $0.64 \pm 0.25$ \\
\hline 57 & 45 & 2.79 & - & $0.51 \pm 4.59 \mathrm{E}-3$ & $0.47 \pm 0.07$ & - & $1.00 \pm 0.06$ \\
\hline \multicolumn{8}{|l|}{58} \\
\hline \multicolumn{8}{|l|}{59} \\
\hline \multicolumn{8}{|l|}{60} \\
\hline 61 & 42.5 & 2.63 & - & $1.05 \pm 0.05$ & $2.14 \pm 0.16$ & - & $0.73 \pm 0.12$ \\
\hline
\end{tabular}

Fig. 11 shows a representative chromatogram for the anions detected in sample 45 .

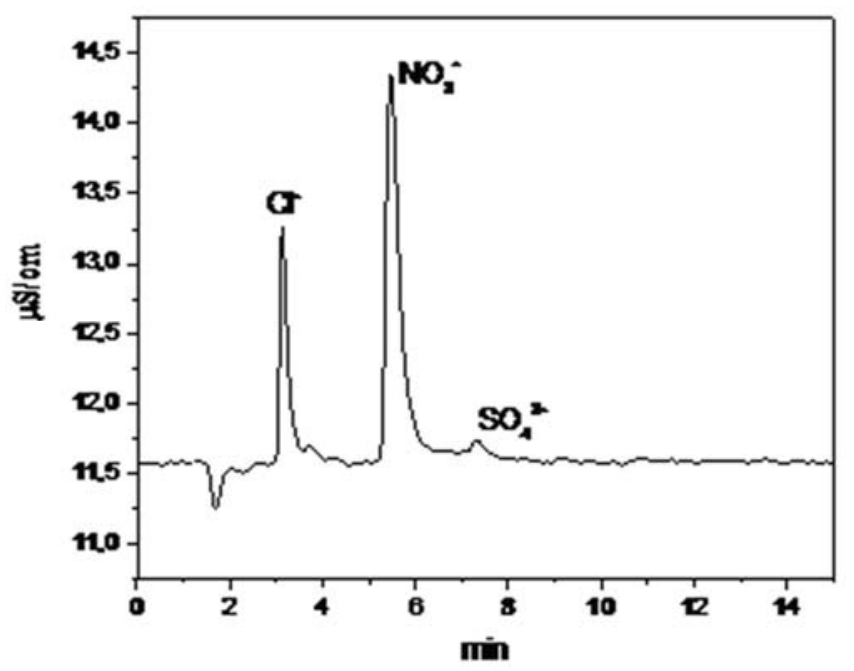

Fig.11. Anion chromatogram for sample 45. Injection volume: $20 \mu \mathrm{l}$; eluent: $2 \mathrm{mmol} / \mathrm{l} \mathrm{NaHCO}_{3} / 1.3 \mathrm{mmol} / \mathrm{l} \mathrm{Na}_{2} \mathrm{CO}_{3}$ in dist. $\mathrm{H}_{2} \mathrm{O}$ with the addition of $1 \%$ of $\mathrm{CH}_{3} \mathrm{CN}$; flow: $1 \mathrm{ml} / \mathrm{min}$

\subsection{Direct shear}

An example of shear stress vs. displacement curve is shown in fig. 12. 


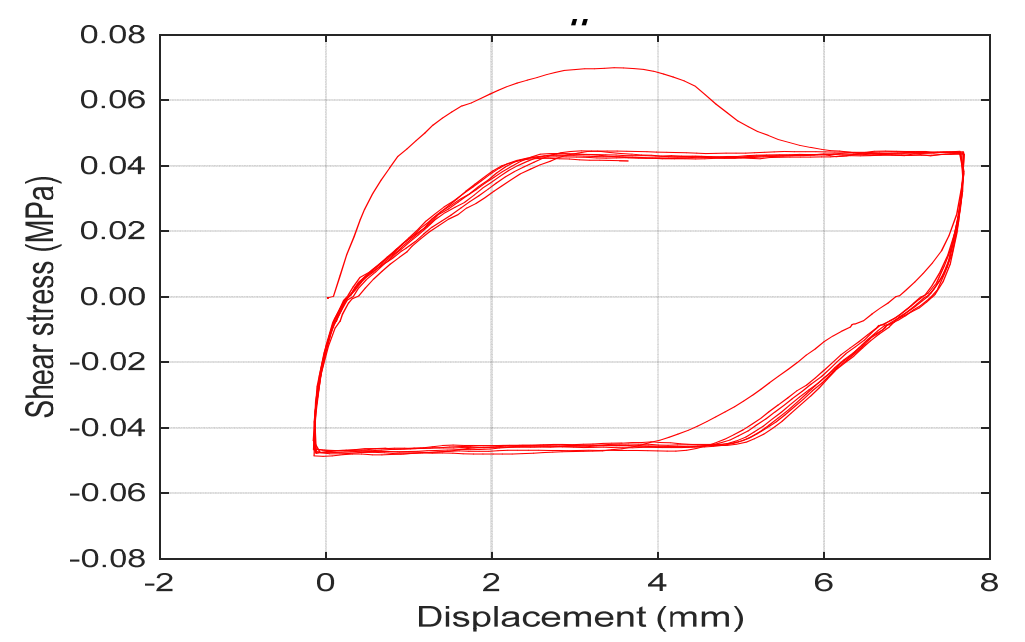

Fig.12. Example of shear force vs. displacement curve (Sample 1, $\sigma_{n}=0.05 \mathrm{MPa}$ )

On the basis of a direct shear test, cohesion $c$ and friction coefficient $\mu$ were determined. The results obtained for Norcia, using maximum shear stress, are shown in Table 4 and fig. 13. As expected [4], cohesion and friction coefficient display a negative correlation.

Table 4. Synthesis of direct shear test (maximum shear stress, Norcia)

$\begin{array}{lll} & \mu[-] & c[\mathrm{kPa}] \\ \max & 1.01 & 37.58 \\ \min & 0.81 & 13.91 \\ \text { mean } & 0.90 & 26.74 \\ \text { std dev } & 0.08 & 8.45 \\ \mathrm{CoV} & 0.09 & 0.32 \\ R & -0.75 & \\ R^{2} & \mathbf{0 . 5 7} & \end{array}$

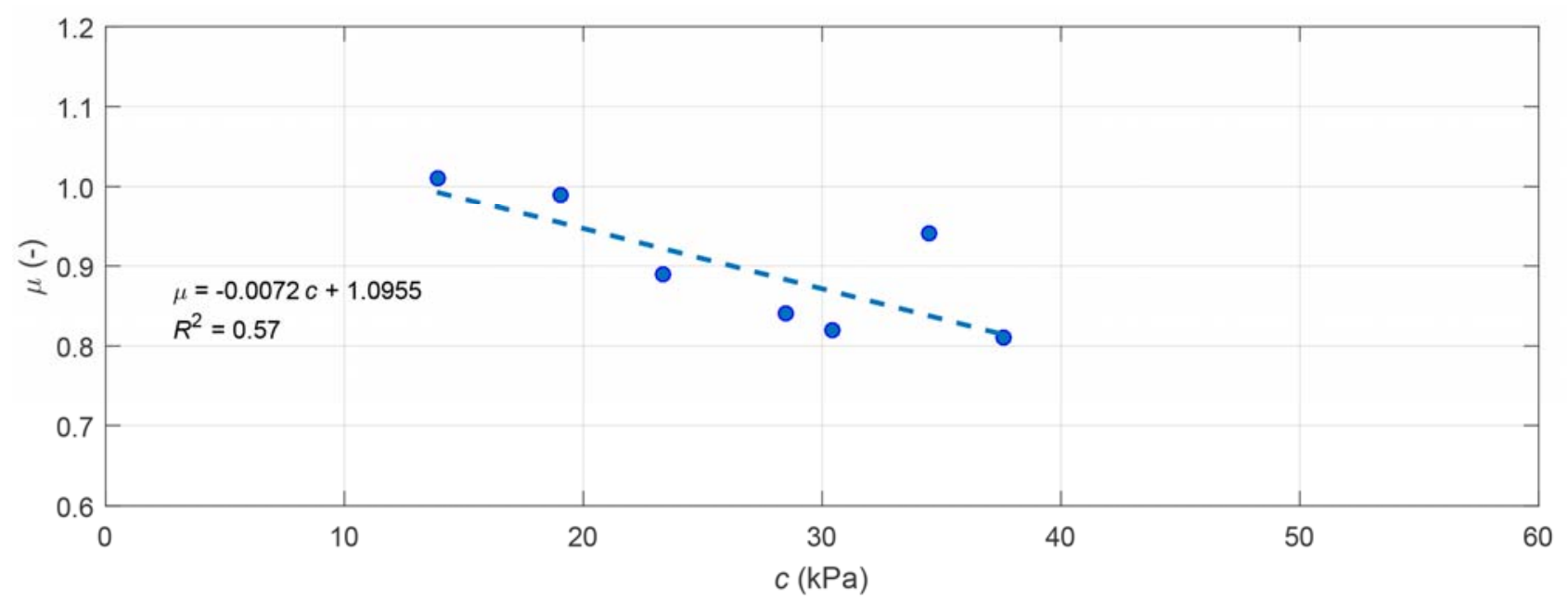

Fig.13. Relation between cohesion and friction coefficient (maximum shear stress, Norcia)

\subsection{Discussion}

The extensive experimental analysis campaign performed for this work made it possible to define a rather clear scenario regarding the quality of bedding mortars used in masonries, mainly in the form of uneven stone walls with bearing function, from different old towns and their neighbourhoods in Central Italy. In particular, the mortars sampled revealed different compositions, which were verified by various methods. The samples from Norcia (Umbria) contained large quantities of calcite, while in those from Arquata del Tronto (Marche), dolomite was largely detected. In the case of Amatrice (Lazio), low quantities of binder 
were detected, consisting mainly of inert fractions, in particular quartz. During sampling, these mortars were in the form of loose powder with few consistent portions. The primary materials used for the preparation of the mortars analysed were probably extracted locally considering the composition of the inert fractions and the presence of dolomite in the area of Arquata del Tronto. Pebbles which were quite rounded in shape could have been extracted from the river Tronto, which flows close to Arquata del Tronto and then on to Amatrice. The presence of similar feldspars and phyllosilicates in the mortars could be related to the presence of these minerals in the sands and pebbles derived from this river. In the case of Norcia, the large quantities of calcite detected in the mortars could be related to the use of limestones, not only for the preparation of slaked lime but also as inert material.

Future work will explore the provenance of construction materials typical of regions in central Italy, since this work is primarily concerned with evaluating the properties of bedding mortars in terms of chemical and physical properties.

\section{Conclusions}

Mortar analyses are customary in the investigation of architectural heritage, aimed at defining historic construction stages, for instance by identifying inert and binder phase as well as the presence of additives. In the case of historical buildings, the investigation of construction materials is useful not only for simple identification but also to evaluate their vulnerability to external events, such as earthquakes.

In this work, mortar samples were studied to qualitatively and semi-quantitatively determine their composition, as well as some of their physical and mechanical properties, in order to correlate these values with the seismic damage surveyed. Sixty-one mortar samples were collected in buildings damaged by the 2016-2017 Central Italian earthquakes, and analysed using several diagnostic techniques, such as: particlesize analysis, X-Ray diffraction, differential scanning calorimetry, calcimetry, Fourier-Transform infrared spectroscopy, solute salt analysis, and direct shear.

Experimental results suggest the use of different materials, in particular mortars obtained from limestone in Umbria (Norcia), dolomitic limestone in Marche (Pretare), and a high quantity of quartz. A large number of samples from Amatrice had a fairly negligible carbonate content, the main component being quartz. This indicates that in these cases the mortars are characterized by the absence of a binder. Mechanical tests confirmed the poor performances of these mortars.

In future work, mortar will be produced in the laboratory, replicating observed compositions but manufacturing standard size specimens to be tested under bending and compression. Moreover, this work could form the basis of territorial seismic risk analyses, wherein vulnerability is also a function of surveyed mortar properties.

Additionally, correlations across regions and centuries could be proposed, based on a statistically robust database. Finally, data on mortar properties could be used in future conservation and restoration schemes, to enhance the compatibility of new and existing materials, and to direct priorities in intervention activity based on the identification of site vulnerability.

\section{References}

[1] L. Sorrentino, S. Cattari, F. Da Porto, G. Magenes, A. Penna, "Seismic Behaviour of Ordinary Masonry Buildings during the 2016 Central Italy Earthquakes",Bulletin of Earthquake Engineering(2018), DOI: 10.1007/s10518-018-0370-4.

[2] Source: INGV - National Institute of Geophysics and Volcanology(http://cnt.rm.ingv.it).

[3] U. Chiocchini, F. Castaldi, "The impact of groundwater on the excavation of tunnels in two different hydrogeological settings in central Italy", Hydrogeology Journal, 19 (2011), pp. 651-669, DOI: 10.1007/s10040-010-0702-1.

[4] D. Liberatore, N. Masini, L. Sorrentino, V. Racina, M. Sileo, O. AlShawa, L. Frezza, "Static penetration test for historical masonry mortar", Construction and Building Materials, 122 (2016), pp. 810-822.

[5] L. Restuccia, A. Lopez, G.A. Ferro, D. Liberatore, J.M. Tulliani, "An investigation of the beneficial effects of adding carbon nanotubes to standard injection grout", Fatigue and Fracture of Engineering Materials and Structures, 41 (2018), pp. 119-128, DOI: 10.1111/ffe.12663.

[6] E. Petrucci, F. Di Lorenzo, "La Storia si ripete: eventi sismici a Norcia fra distruzione e ricostruzione" in Reuso 2017, Sobre una Architectura Hecha de Tiempo - Metodología, Técnica y Conservación, Granada 18-21 ottobre 2017, Universidad De Granada, vol. 1, pp. 453-459, ISBN 978-84-3386-13-13.

[7] R. Sisti, M. Di Ludovico, A. Borri, A. Prota, "Damage Assessment and the Effectiveness of Prevention: The Response of Ordinary Unreinforced Masonry Buildings in Norcia during the Central Italy 2016- 
2017 Seismic Sequence”, Bulletin of Earthquake Engineering, accepted (2018),DOI:10.1007/s10518018-0448-z.

[8] C. Groot, G. Ashall, J. Hughes, "Characterization of Old Mortars with Respect to their Repair", Final Report of RILEM TC 167-COM (1996).

[9] C. Carrara, F. Persia, "Indagini mineralogiche-petrografiche e di diffrazione dei raggi X sulle incrostazioni calcaree e sulle malte" in Gli acquedotti Claudio e Aniene Nuovo nell'area della Banca d'Italia in Via Tuscolana, Ed Istituto Poligrafico e Zecca dello Stato (2001), pp. 193-197.

[10] V. Cardinale, F. Persia, L. Campanella, F. Cardellini, S. Omarini, "Storia costruttiva del complesso monastico di San Vincenzo al Volturno attraverso la determinazione di differenze composizionali nelle malte. Risultati preliminari”, Atti del $2^{\circ}$ Congresso Nazionale AIAr, Bologna 29 gennaio-1 febbraio 2002, pp. 505-513, ISBN 88-555-2688.

[11] G. Chiari, M.L. Santarelli, G. Torraca, "Caratterizzazione delle malte antiche mediante l'analisi di campioni non frazionati”, anno II, n. 3 (1992).

[12] R.M. Dheilly, A. Bouguerra, B. Beaudoin, J. Tudo, M. Queneudec, "Hydromagnesite development in magnesian lime mortars", Materials Science and Engineering A268 (1999), pp. 127-131.

[13] A. Arizzi, G. Cultrone, "The difference in behaviour between calcitic and dolomitic lime mortars set under dry conditions: The relationship between textural and physical-mechanical properties", Cement and Concrete Research, Volume 42, Issue 6 (2012), pp. 818-826.

[14] M. Olszak-Humienik, M. Jablonski, "Thermal behavior of natural dolomite", J Therm Anal Calorim 119 (2015), pp. 2239-2248.

[15] L. Chever, S. Pavìa, R. Howard, "Physical properties of magnesian lime mortars", Materials and Structures, 43 (2010), pp. 283-296.

[16] M. Gulmini, G. Roselli, F. Scognamiglio, G. Vaggelli, "Composition and microstructure of maiolica from the museum of ceramics in Ascoli Piceno (Italy): evidences by electron microscopy and microanalysis", Applied Physics A, Volume 120, Issue 4 (2015), pp. 1643-1652. 